\title{
Article \\ The Semen Microbiome and Semen Parameters in Healthy Stallions
}

\author{
Carlota Quiñones-Pérez ${ }^{1, *(\mathbb{D})}$, Amparo Martínez ${ }^{2}$ (D) Isabel Ortiz $^{3}$ (D) Francisco Crespo ${ }^{4}$ (D) \\ and José Luis Vega-Pla ${ }^{1}(\mathbb{D}$
}

1 Laboratorio de Investigación Aplicada, Cría Caballar de las Fuerzas Armadas, Carretera de Madrid Km 395A, 14014 Córdoba, Spain; jvegpla@oc.mde.es

2 Genetics Department, Edificio Gregor Mendel (C5), Campus de Rabanales, University of Córdoba, 14071 Córdoba, Spain; amparomartinezuco@gmail.com

3 Veterinary Reproduction Group, Department of Animal Medicine and Surgery, Campus Rabanales, University of Córdoba, 14071 Córdoba, Spain; isabel.ortiz.vet@gmail.com

4 Centro Militar de Cría Caballar de Ávila, Cría Caballar de las Fuerzas Armadas, Calle Arsenio Gutiérrez Palacios, 05005 Ávila, Spain; fcrecas@oc.mde.es

* Correspondence: cquiper@mde.es

Citation: Quiñones-Pérez, C. Martínez, A.; Ortiz, I.; Crespo, F.; Vega-Pla, J.L. The Semen Microbiome and Semen Parameters in Healthy

Stallions. Animals 2022, 12, 534.

https://doi.org/10.3390/ani12050534

Academic Editors: Jordi

Ribas-Maynou, Albert Salas-Huetos and Isabel Barranco

Received: 29 December 2021

Accepted: 17 February 2022

Published: 22 February 2022

Publisher's Note: MDPI stays neutral with regard to jurisdictional claims in published maps and institutional affiliations.

Copyright: (C) 2022 by the authors. Licensee MDPI, Basel, Switzerland. This article is an open access article distributed under the terms and conditions of the Creative Commons Attribution (CC BY) license (https:// creativecommons.org/licenses/by/ $4.0 /)$.
Simple Summary: Stallion infertility is a major cause of concern in the horse industry. Despite zootechnics advances, sub- or infertile animals appear in stud farms without a toxic, genetic, or nutritional reason. Recent research in human andrology has opened the door for a new, plausible factor that affects sperm quality: seminal microflora. In recent years, there has been an increasing amount of evidence regarding the relationship between different seminal flora compositions and male fertility. However, little has been studied in veterinary science, including horses. Therefore, the objective of this study was to examine associations with the presence of bacteria families in horse semen with five sperm quality parameters: concentration, total number of spermatozoa, total and progressive sperm motility, and DNA fragmentation. Our study detected a correlation between the presence of the Peptoniphilaceae family and higher total motility and the presence of Clostridiales Incertae Sedis XI and lower progressive motility. These changes in seminal flora may contribute to the idiopathically poorer sperm quality in certain animals. Although further mechanisms behind bacteria-spermatozoa interactions are unknown, these associations are already leading to a new therapeutic approach to infertility: the use of prebiotics, which has already yielded promising results in human andrology.

Abstract: Despite the advances in reproductive technology, there is still a considerable number of low sperm quality cases in stallions. Recent studies in humans have detected several seminal microflora-spermatozoa associations behind some idiopathic infertility cases. However, no studies are available on horses, and there is limited information on the microflora present in stallion ejaculates. Accordingly, the objective of this study was to examine associations to the presence of bacteria families with five sperm quality parameters: concentration, total number of spermatozoa, total and progressive motility, and DNA fragmentation. Samples were cryopreserved after their extraction. High-speed homogenization using grinding media was performed for cell disruption. Family identification was performed via $16 \mathrm{~S}$ rRNA sequencing. Bacterial families were only considered if the relative abundance was higher than $1 \%$. Only two families appeared to have a correlation with two sperm quality parameters. Peptoniphilaceae correlated positively with total sperm motility, whereas Clostridiales Incertae Sedis XI correlated negatively with progressive motility. No significant differences were found for the rest of the parameters. In conclusion, the seminal microbiome may affect spermatozoa activity. Our findings are based on statistical associations; thus, further studies are needed to understand the internal interactions between seminal flora and cells.

Keywords: microbiome; stallion; sperm quality; motility 


\section{Introduction}

The success of the equine industry greatly depends on good reproductive outcomes. These outcomes depend on a variety of factors, such as sperm quality. There are objective parameters that assess sperm quality, such as concentration, total motility, or progressive motility [1-3]. Factors affecting these parameters have been subject to large-scale analysis in horse reproductive science [4].

In recent years, the microbiome has proven to have a great impact on the systems they dwell on [5-9]. Unfortunately, the male reproductive tract has not received sufficient attention $[10,11]$. In the human species, however, some authors have already pointed out the influence of bacteria on semen quality [12-16]. In fact, these studies have opened the door to a potential therapeutic tool in infertility cases, and some authors have already published some positive effects of prebiotics in improving sperm quality [17-20].

Unfortunately, in veterinary science, research focuses on animal experimentation, such as mice [17] or broilers [18]. Regarding stallions, papers usually focus on pathogenic bacteria [21] or on their effect on reproductive technologies [22,23]. Besides, these are usually culture-based studies, which may underestimate the presence of some difficult-toculture bacteria [24].

To the best of our knowledge, there are no studies evaluating sperm quality and the seminal microbiome in this species. Therefore, the objective of this study was to assess the relationship between the presence of more abundant bacteria and five sperm quality parameters: concentration, total number of spermatozoa, total and progressive sperm motility, and DNA fragmentation.

\section{Materials and Methods}

\subsection{Materials}

\subsubsection{Sample Collection}

All the experiments were performed in accordance with the Spanish law for animal welfare and experimentation (Decision 2012/707/UE and RD 53/2013). Animals belonged to the Equine Breeding Centre of the Spanish Army of Écija. Animals lived in accordance with the Spanish law for animal welfare (Law 32/07). Semen was opportunistically collected during daily work to avoid extra collections.

Samples were collected from 12 clinically stallions (7 Andalusians, 4 Arabs, and 1 Anglo-Arab) in Écija (Seville, Spain) during the breeding season (March-June). Stallions were collected a maximum of 3 times per week, with at least $48 \mathrm{~h}$ between collections. Age ranged from 6 to 23 years old, mean $13.3 \pm 5.2$ standard deviation (Table 1). Semen collection was performed using a phantom for stallion support, with a mare in estrus to stimulate sexual behavior. Semen was collected using a Missouri-type artificial vagina (Minitüb ${ }^{\circledR}$, Tiefenbach, Germany) with an in-line filter. In order to prevent contamination, personnel wore gloves during the whole process of collection, preparation, and evaluation of ejaculates. An inner disposable sterile plastic liner was used for each animal. It was internally spread with a sterile, silicon-free commercial lubricant (Vet Gel, Kerbl ${ }^{\circledR}$, Buchbach, Germany). At the beginning of the breeding season, the penis and prepuce of the stallion were gently washed with warm water to remove smegma excess. No routinary penis preparation prior to collection was performed unless there was smegma accumulation. Animals were housed in individual boxes with straw bedding, fed under the same dietary conditions, and had the same exercise regime. Diet included alfalfa hay, commercial concentrate, and oats.

Each sample was divided into two aliquots to evaluate: (i) Sperm quality: raw semen was extended with INRA96 ${ }^{\circledR}$ (IMV, L'Aigle, France) until reaching $25 \times 10^{6}$ sperm $/ \mathrm{mL}$ to assess sperm parameters (Table 1); and (ii) Microbiome: raw semen was frozen immediately after collection following the method described in [25], prior to analysis using next-generation sequencing as detailed below. 
Table 1. Sperm quality analysis: Numbers represent animals. PRE: Andalusian. Aa: Anglo-Arabian. Ar: Arabian. C: sperm concentration (millions of cells $/ \mathrm{mL}$ ). NSPZ: total number of sperm (millions). TM: total sperm motility (\%). PM: progressive sperm motility (\%). Frag: sperm DNA fragmentation (\%).

\begin{tabular}{ccccccc}
\hline & Breed & C & NSPZ & TM & PM & Frag \\
\hline 1 & Ar & 163 & 6520 & 80.0 & 38.0 & 6.0 \\
2 & Aa & 79 & 6715 & 80.0 & 40.0 & 6.7 \\
3 & Ar & 372 & 3348 & 91.0 & 42.0 & 4.3 \\
4 & PRE & 232 & 9280 & 70.0 & 25.0 & 11.7 \\
5 & PRE & 227 & 6810 & 75.0 & 25.0 & 8.3 \\
6 & PRE & 374 & 9350 & 80.0 & 50.0 & 3.3 \\
7 & PRE & 220 & 12,100 & 90.0 & 25.0 & 5.0 \\
8 & PRE & 377 & 3770 & 77.0 & 43.0 & 8.0 \\
9 & PRE & 392 & 7840 & 75.0 & 25.0 & 4.0 \\
10 & Ar & 307 & 6140 & 68.0 & 36.0 & 7.7 \\
11 & PRE & 230 & 8050 & 85.0 & 57.0 & 5.0 \\
\hline
\end{tabular}

\subsubsection{Control Sample}

In order to evaluate the extraction and amplification quality, the pattern sample ZymoBIOMICS Microbial Community Standard ${ }^{\circledR}$ (Zymo Research, Irvine, CA, USA) was included during DNA extraction.

\subsection{Methods}

\subsubsection{Sperm Parameters Evaluation}

Sperm concentration was measured using a spectrophotometer (Spermacue ${ }^{\circledR}$, Minitüb, Tiefenbach, Germany). The total number of spermatozoa was calculated by multiplying the concentration and volume. Then, semen was diluted until reaching an approximate concentration of $25 \times 10^{6}$ sperm $/ \mathrm{mL}$ in milk-based extender (INRA $96^{\circledR}$, IMV Technologies, L'Aigle, France) and placed in a $37^{\circ} \mathrm{C}$ water bath. The extender contains fractions of milk micellar proteins, penicillin, gentamicin, and amphotericin B. Extended semen was only used for sperm parameters evaluation.

Sperm motility was evaluated using computer-assisted sperm analysis (Sperm Class Analyzer ${ }^{\circledR}$, SCA, Microptic SL, Barcelona, Spain) using a $37{ }^{\circ} \mathrm{C}$ heated plate and a phasecontrast microscope (Optiphot-2, Nikon ${ }^{\circledR}$, Tokyo, Japan). Chamber slides were pre-heated at $37^{\circ} \mathrm{C}$ and up with the extended samples. Total (TM, \%) and progressive sperm motility (PM, \%) were evaluated as described by [25]. The minimum number of cells per sample analyzed was 500.

Sperm DNA fragmentation was assessed with the Sperm Halomax kit ${ }^{\circledR}$ (Halotech DNA $^{\circledR}$ SL, Madrid, Spain), as described in [26].

\subsubsection{DNA Extraction}

DNA extraction was performed using a ZymoBIOMICS ${ }^{\circledR}$ DNA Miniprep (Zymo Research ${ }^{\circledR}$, CA, USA) commercial kit. Samples had been previously submitted to a combination of mechanic and enzymatic-digestion cell disruption, as described by Bag [27]. Briefly, $100 \mu \mathrm{L}$ of the raw semen sample was broken down for $1 \mathrm{~h}$ with $10 \mathrm{mg} / \mathrm{mL}$ lysozyme, $4000 \mathrm{U} / \mathrm{mL}$ lysophosphatin, and 25,000 U/mL mutanolysin. Then, samples were mechanically disrupted by high-speed homogenization (5000 rpm for $5 \mathrm{~min}$ ) in grinding media (0.1 and $0.5 \mathrm{~mm}$-diameter ceramics beads). Then, DNA was extracted following the manufacturer's instructions.

\subsubsection{Next-Generation Sequencing Analysis}

Next-generation analysis was performed using Ion semiconductor sequencing following the protocol described by Quiñones [28]. 
Data analysis was performed in the Ion Reporter server system (https: / /ionreporter. thermofisher.com/ir/secure/home.html) (accessed on 15 October 2021). Hypervariable region V3 was chosen for bacterial identification, as it has been suggested to detect a wider range of bacterial species [29].

\subsubsection{Statistical Analysis}

Bray-Curtis dissimilarity was calculated among animals (Table 2) using the following formula:

$$
\mathrm{BC}_{\mathrm{i}, \mathrm{j}}=1-\frac{2 \times \mathrm{B}_{\mathrm{i}, \mathrm{j}}}{\mathrm{A}_{\mathrm{i}}+\mathrm{B}_{\mathrm{j}}}
$$

$\mathrm{BC}_{\mathrm{i}, \mathrm{j}}=$ Bray-Curtis dissimilarity.

$\mathrm{B}_{\mathrm{i}, \mathrm{j}}=$ sum of the lesser count of common families in groups A and B.

$\mathrm{A}_{\mathrm{i}}=$ total number of bacterial families in group $\mathrm{A}$.

$\mathrm{B}_{\mathrm{j}}=$ total number of bacterial families in group $\mathrm{B}$.

Values range from 0 to 1 . Values closer to 1.00 mean more dissimilarity between groups. Statistical analysis was performed using Microsoft Excel ${ }^{\circledR} 2013$.

Table 2. Bray-Curtis dissimilarity. Values closer to 1.00 mean more dissimilarity between samples. Numbers represent animals. PRE: Andalusian. Aa: Anglo-Arabian. Ar: Arabian. Values range from 0 to 1 . Values closer to 1.00 mean more dissimilarity between groups.

\begin{tabular}{cccccccccccccc}
\hline & Breed & $\mathbf{1}$ & $\mathbf{2}$ & $\mathbf{3}$ & $\mathbf{4}$ & $\mathbf{5}$ & $\mathbf{6}$ & $\mathbf{7}$ & $\mathbf{8}$ & $\mathbf{9}$ & $\mathbf{1 0}$ & $\mathbf{1 1}$ & $\mathbf{1 2}$ \\
\hline 1 & Ar & - & - & - & - & - & - & - & - & - & - & - \\
2 & Aa & 0.21 & - & - & - & - & - & - & - & - & - & - \\
3 & Ar & 0.02 & 0.21 & - & - & - & - & - & - & - & - & - \\
4 & PRE & 0.20 & 0.15 & 0.22 & - & - & - & - & - & - & - & - \\
5 & PRE & 0.32 & 0.18 & 0.34 & 0.15 & - & - & - & - & - & - & - & - \\
6 & PRE & 0.23 & 0.22 & 0.24 & 0.18 & 0.21 & - & - & - & - & - & - & - \\
7 & PRE & 0.46 & 0.41 & 0.48 & 0.31 & 0.27 & 0.26 & - & - & - & - & - & - \\
8 & PRE & 0.22 & 0.26 & 0.24 & 0.26 & 0.44 & 0.13 & 0.35 & - & - & - & - & - \\
9 & PRE & 0.45 & 0.40 & 0.47 & 0.27 & 0.22 & 0.35 & 0.25 & 0.46 & - & - & - & - \\
10 & Ar & 0.45 & 0.39 & 0.47 & 0.36 & 0.21 & 0.24 & 0.10 & 0.33 & 0.20 & - & - & - \\
11 & PRE & 0.42 & 0.42 & 0.44 & 0.36 & 0.31 & 0.22 & 0.04 & 0.31 & 0.32 & 0.22 & - & - \\
12 & Ar & 0.39 & 0.32 & 0.37 & 0.28 & 0.19 & 0.17 & 0.13 & 0.25 & 0.27 & 0.16 & 0.12 & - \\
\hline
\end{tabular}

\section{Results}

Quality control was performed by submitting the ZymoBIOMICS Microbial Community Standard ${ }^{\circledR}$ to the same extraction and analysis process as the rest of the samples. The resulting composition showed minor variations compared to that provided by the manufacturer (Figure 1).

Then, samples were submitted to a sperm quality analysis. Concentration, number of spermatozoa, total and progressive sperm motility parameters, and sperm DNA fragmentation were included. Results are represented in Table 1.

Four common phyla were detected in samples and a total of 74 families. Phyla results are represented in Figure 2.

Then, Bray-Curtis dissimilarity was calculated between animals. Results are represented in Table 2. 


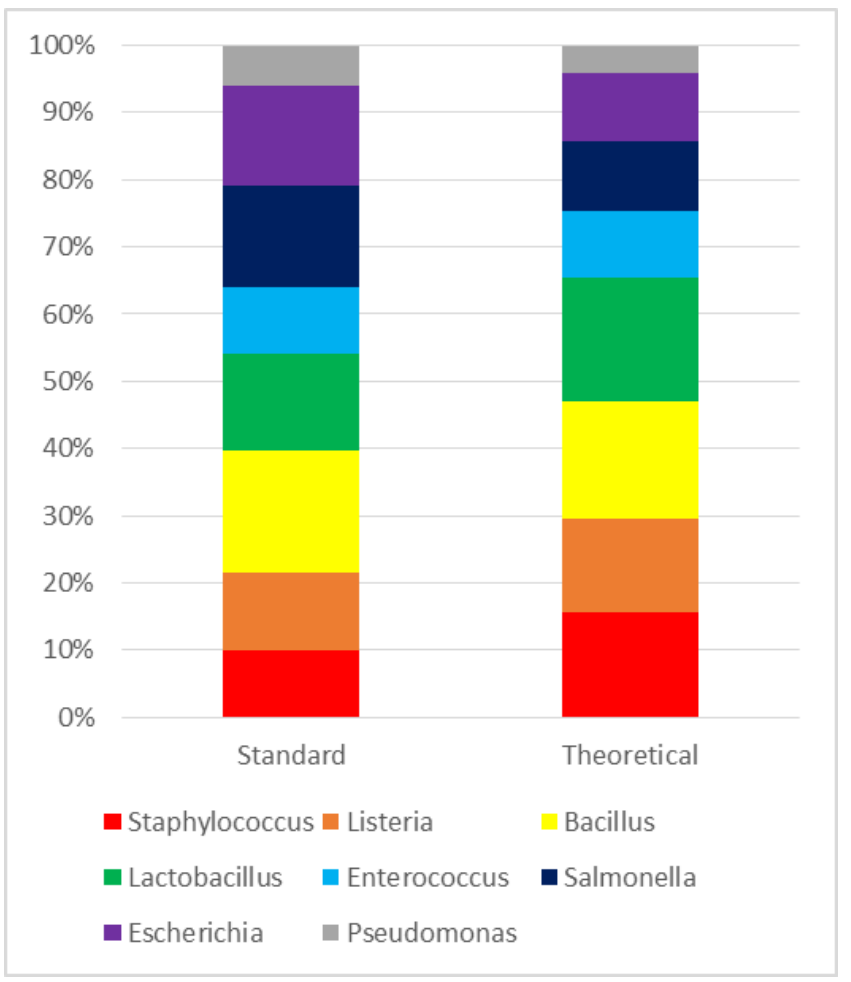

Figure 1. Bacterial composition of standard sample compared to its theoretical composition. Results are expressed as a percentage $(\%)$.

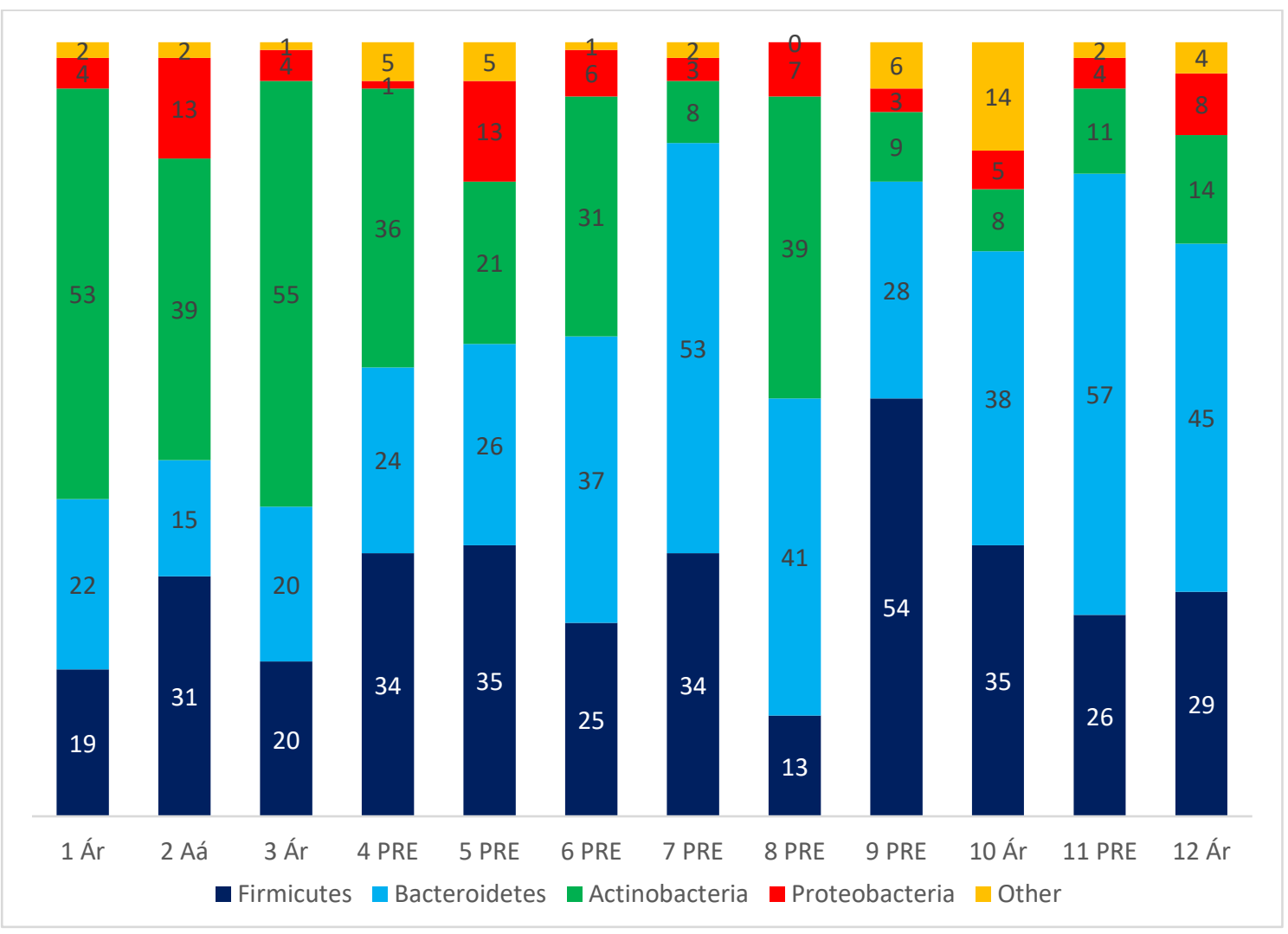

Figure 2. Graphical representation of bacteria the four more abundant phyla in samples. Numbers in $X$ axis represent animals. PRE: Andalusian. Aa: Anglo-Arabian. Ar: Arabian. Numbers inside the bars represent the percentage of abundance of each phyla. 


\section{Discussion}

Our results show that there might be a correlation between some sperm quality parameters and the seminal flora composition of healthy, fertile stallions, in particular, Firmicutes phylum. Although there are some individual differences, the more abundant phyla are common in all animals. Starting with Firmicutes phylum, the literature contains divergent findings regarding the effect of bacterial families on sperm quality. Some authors have highlighted the positive correlation between specific Firmicutes families and good sperm quality. In this regard, Lactobacillus gender has been proven to have a protective effect on spermatozoa [13,30-32]. The mechanisms of protection are not fully understood, but they may be related to the antioxidant products exerted by lactobacilli in the extracellular environment [32]. Additionally, the positive effects of lactobacilli supplementation on sperm quality parameters have also been described in humans [19,20], mice [17], and broilers [18]. Stallion semen is not abundant in the Lactobacillus genus [10,11], but there are related bacterial families.

However, other authors have found some Firmicutes to have a detrimental effect on sperm parameters. In the literature, we found Anaerococcus, a Clostridiales genus, to have a detrimental effect on sperm quality $[15,33]$. The underlying mechanism needs to be further studied. Another detrimental family is Mycoplasmataceae (specifically, its Ureaplama genus) [24,34-36], whose pathogenic activity lies in acrosome damage [35]. This family was not detected in our samples.

A dominant family in fertile stallions is Porphyromonadaceae [11]. According to our results, this family is highly abundant, as it represents almost the whole Bacteroidetes phylum. This family seems to be a natural component in fertile males [15,34]; however, it is not as abundant as it is in horses. Regarding this family, it is necessary to highlight that it is difficult to find in culture-based references, as it is a laborious process to culture bacteria. The other highly dominant family in stallion semen is Corynebacteriaceae [10,11], which has regularly been found in fertile individuals [10,23,37-40]. However, some authors consider it has an opportunistic character [22,33,41]. It has been associated with a higher activity of caspases [22], which is usually linked to apoptosis [42]. Its predominance has also been linked to low motility [43].

Most infertility-related bacteria families belong to the Proteobacteria phylum, particularly to the Gammaproteobacteria class $[13,24,35,44]$. Enterobacteriaceae is included in this group, which has been found to alter spermatozoa motility $[22,35]$ and the proportion of dead spermatozoa [22]; and Pseudomonadaceae [13,24,35,39,40], which may contain opportunistic pathogenic species [13,45]. In stallions, the presence of the Enterobacteriaceae family typically has a fecal origin [46] and worsens various seminal parameters [22,39,40]. Regarding Pseudomonadaceae, this family has been related to lower values of motility and integrity parameters $[23,46,47]$, while other authors agree to consider it an opportunistic pathogen [40]. However, this family has been regularly found in the semen of fertile stallions [46,48]. The negative impact of these two families has also been found in boars [45]. In our case, Enterobacteriaceae only appeared in one horse $(0.19 \%)$ and Pseudomonadaceae in just two $(0.06 \%$ and $0.04 \%)$.

Bacteria in stallion semen have long been associated with a detrimental impact on fertility [23] as well as with a lower storage capacity [22]. Our study wanted to show that there may be certain bacterial families that harmoniously dwell in semen.

Regarding the strengths and limitations of our paper, next-generation sequencing is a better tool to characterize the seminal flora, as it overcomes laborious-to-culture bacteria $[10,11,28,49]$. However, the data process may be more complicated [50]. Finally, we mostly compared our findings with those of experiments carried out on humans, as animal references are extremely scarce. Further studies including a larger number of animals, including subfertile stallions with low sperm quality, are needed in order to find the possible relationship between the seminal microbiome and sperm quality. 


\section{Conclusions}

In conclusion, four common bacterial phyla are present in all the stallions evaluated: Firmicutes, Bacteroidetes, Actinobacteria, and Proteobacteria. Although proportions vary among individuals, sperm quality values are similar. Further studies are needed to better understand the interactions between seminal flora and sperm quality.

Author Contributions: Conceptualization, C.Q.-P. and J.L.V.-P.; formal analysis, C.Q.-P.; resources, A.M.; writing-original draft preparation, C.Q.-P.; writing-review and editing, A.M., F.C., I.O., and J.L.V.-P.; visualization, C.Q.-P. All authors have read and agreed to the published version of the manuscript.

Funding: This research received no external funding.

Institutional Review Board Statement: The Bioethics and Biosafety Committee of the University of Córdoba considers this study is exempt from ethics approval. It considers that it has had no impact on animal welfare because the procedure performed on animals was part of routine animal husbandry and did not involve harm to the animal. The animals used in the study were legally in accordance with the Spanish law for animal welfare (Law 32/07, of 7 November, for the care of animalsin their exploitation, transport, experimentation and slaughter).

Informed Consent Statement: Not applicable.

Data Availability Statement: Data are contained within the article.

Acknowledgments: The authors would like to thank Diputación de Córdoba for their technical assistance.

Conflicts of Interest: The authors declare no conflict of interest.

\section{References}

1. Jasko, D.J. Evaluation of Stallion Semen. Vet. Clin. N. Am. Equine Pract. 1992, 8, 129-148. [CrossRef]

2. Malmgren, L. Assessing the Quality of Raw Semen: A Review. Theriogenology 1997, 48, 523-530. [CrossRef]

3. Love, C.C. Sperm Quality Assays: How Good Are They? The Horse Perspective. Anim. Reprod. Sci. 2018, 194, 63-70. [CrossRef] [PubMed]

4. McKinnon, A.O.; Squires, E.L.; Vaala, W.E.; Varner, D.D. Equine Reproduction, 2nd ed.; Wiley-Blackwell: Hoboken, NJ, USA, 2011; ISBN 978-0-8138-1971-6.

5. Ericsson, A.C.; Johnson, P.J.; Lopes, M.A.; Perry, S.C.; Lanter, H.R. A Microbiological Map of the Healthy Equine Gastrointestinal Tract. PLoS ONE 2016, 11, e0166523. [CrossRef]

6. Manguin, E.; Pépin, E.; Boivin, R.; Leclere, M. Tracheal Microbial Populations in Horses with Moderate Asthma. J. Vet. Intern. Med. 2020, 34, 986-995. [CrossRef]

7. LaFrentz, S.; Abarca, E.; Mohammed, H.H.; Cuming, R.; Arias, C.R. Characterization of the Normal Equine Conjunctival Bacterial Community Using Culture-Independent Methods. Vet. Ophthalmol. 2020, 23, 230-238. [CrossRef]

8. Barba, M.; Martínez-Boví, R.; Quereda, J.J.; Mocé, M.L.; Plaza-Dávila, M.; Jiménez-Trigos, E.; Gómez-Martín, Á.; González-Torres, P.; Carbonetto, B.; García-Roselló, E. Vaginal Microbiota Is Stable throughout the Estrous Cycle in Arabian Maress. Animals 2020, 10, 2020. [CrossRef]

9. Costa, M.C.; Silva, G.; Ramos, R.V.; Staempfli, H.R.; Arroyo, L.G.; Kim, P.; Weese, J.S. Characterization and Comparison of the Bacterial Microbiota in Different Gastrointestinal Tract Compartments in Horses. Vet. J. 2015, 205, 74-80. [CrossRef]

10. Al-Kass, Z.; Guo, Y.; Vinnere Pettersson, O.; Niazi, A.; Morrell, J.M. Metagenomic Analysis of Bacteria in Stallion Semen. Anim. Reprod. Sci. 2020, 221, 106568. [CrossRef]

11. Quiñones-Pérez, C.; Hidalgo, M.; Ortiz, I.; Crespo, F.; Vega-Pla, J.L. Characterization of the Seminal Bacterial Microbiome of Healthy, Fertile Stallions Using next-Generation Sequencing. Anim. Reprod. 2021, 18, e20200052. [CrossRef]

12. Tomaiuolo, R.; Veneruso, I.; Cariati, F.; D'Argenio, V. Microbiota and Human Reproduction: The Case of Male Infertility. High Throughput 2020, 9, 10. [CrossRef] [PubMed]

13. Weng, S.-L.; Chiu, C.-M.; Lin, F.-M.; Huang, W.-C.; Liang, C.; Yang, T.; Yang, T.-L.; Liu, C.-Y.; Wu, W.-Y.; Chang, Y.-A.; et al. Bacterial Communities in Semen from Men of Infertile Couples: Metagenomic Sequencing Reveals Relationships of Seminal Microbiota to Semen Quality. PLoS ONE 2014, 9, e110152. [CrossRef] [PubMed]

14. Altmäe, S.; Franasiak, J.M.; Mändar, R. The Seminal Microbiome in Health and Disease. Nat. Rev. Urol. 2019, 16, 703-721. [CrossRef] [PubMed]

15. Hou, D.; Zhou, X.; Zhong, X.; Settles, M.L.; Herring, J.; Wang, L.; Abdo, Z.; Forney, L.J.; Xu, C. Microbiota of the Seminal Fluid from Healthy and Infertile Men. Fertil. Steril. 2013, 100, 1261-1269. [CrossRef] 
16. Zhang, J.; Liu, H.; Yang, Q.; Li, P.; Wen, Y.; Han, X.; Li, B.; Jiang, H.; Li, X. Genomic Sequencing Reveals the Diversity of Seminal Bacteria and Relationships to Reproductive Potential in Boar Sperm. Front. Microbiol. 2020, 11, 1873. [CrossRef]

17. Dardmeh, F.; Alipour, H.; Gazerani, P.; van der Horst, G.; Brandsborg, E.; Nielsen, H.I. Lactobacillus Rhamnosus PB01 (DSM 14870) Supplementation Affects Markers of Sperm Kinematic Parameters in a Diet-Induced Obesity Mice Model. PLoS ONE 2017, 12, e0185964. [CrossRef]

18. Inatomi, T.; Otomaru, K. Effect of Dietary Probiotics on the Semen Traits and Antioxidative Activity of Male Broiler Breeders. Sci. Rep. 2018, 8, 5874. [CrossRef]

19. Maretti, C.; Cavallini, G. The Association of a Probiotic with a Prebiotic (Flortec, Bracco) to Improve the Quality/Quantity of Spermatozoa in Infertile Patients with Idiopathic Oligoasthenoteratospermia: A Pilot Study. Andrology 2017, 5, 439-444. [CrossRef]

20. Valcarce, D.G.; Genovés, S.; Riesco, M.F.; Martorell, P.; Herráez, M.P.; Ramón, D.; Robles, V. Probiotic Administration Improves Sperm Quality in Asthenozoospermic Human Donors. Benef. Microbes 2017, 8, 193-206. [CrossRef]

21. Samper, J.C. Equine Breeding Management and Artificial Insemination; Elsevier Health Sciences: Amsterdam, The Netherlands, 2009; ISBN 978-1-4160-5234-0.

22. Ortega-Ferrusola, C.; González-Fernández, L.; Muriel, A.; Macías-García, B.; Rodríguez-Martínez, H.; Tapia, J.A.; Alonso, J.M.; Peña, F.J. Does the Microbial Flora in the Ejaculate Affect the Freezeability of Stallion Sperm? Reprod. Domest. Anim. 2009, 44, 518-522. [CrossRef]

23. Varela, E.; Rey, J.; Plaza, E.; Muñoz de Propios, P.; Ortiz-Rodríguez, J.M.; Álvarez, M.; Anel-López, L.; Anel, L.; De Paz, P.; Gil, M.C.; et al. How Does the Microbial Load Affect the Quality of Equine Cool-Stored Semen? Theriogenology 2018, 114, 212-220. [CrossRef] [PubMed]

24. Moretti, E.; Capitani, S.; Figura, N.; Pammolli, A.; Federico, M.G.; Giannerini, V.; Collodel, G. The Presence of Bacteria Species in Semen and Sperm Quality. J. Assist. Reprod Genet. 2009, 26, 47-56. [CrossRef] [PubMed]

25. Crespo, F.; Quiñones-Pérez; Ortiz, I.; Diaz-Jimenez, M.; Consuegra, C.; Pereira, B.; Dorado, J.; Hidalgo, M. Seasonal Variations in Sperm DNA Fragmentation and Pregnancy Rates Obtained after Artificial Insemination with Cooled-Stored Stallion Sperm throughout the Breeding Season (Spring and Summer). Theriogenology 2020. [CrossRef] [PubMed]

26. López-Fernández, C.; Crespo, F.; Arroyo, F.; Fernández, J.L.; Arana, P.; Johnston, S.D.; Gosálvez, J. Dynamics of Sperm DNA Fragmentation in Domestic Animals. Theriogenology 2007, 68, 1240-1250. [CrossRef] [PubMed]

27. Bag, S.; Saha, B.; Mehta, O.; Anbumani, D.; Kumar, N.; Dayal, M.; Pant, A.; Kumar, P.; Saxena, S.; Allin, K.H.; et al. An Improved Method for High Quality Metagenomics DNA Extraction from Human and Environmental Samples. Sci. Rep. 2016, 6, 26775. [CrossRef] [PubMed]

28. Quiñones-Pérez, C.; Martinez, A.; Crespo, F.; Vega-Pla, J.L. Comparative Semen Microbiota Composition of a Stallion in a Taylorella Equigenitalis Carrier and Non-Carrier State. Animals 2020, 10, 868. [CrossRef] [PubMed]

29. Chakravorty, S.; Helb, D.; Burday, M.; Connell, N.; Alland, D. A Detailed Analysis of 16S Ribosomal RNA Gene Segments for the Diagnosis of Pathogenic Bacteria. J. Microbiol. Methods 2007, 69, 330-339. [CrossRef]

30. Monteiro, C.; Marques, P.I.; Cavadas, B.; Damião, I.; Almeida, V.; Barros, N.; Barros, A.; Carvalho, F.; Gomes, S.; Seixas, S. Characterization of Microbiota in Male Infertility Cases Uncovers Differences in Seminal Hyperviscosity and Oligoasthenoteratozoospermia Possibly Correlated with Increased Prevalence of Infectious Bacteria. Am. J. Reprod. Immunol. 2018, 79 , e12838. [CrossRef]

31. Mändar, R.; Punab, M.; Borovkova, N.; Lapp, E.; Kiiker, R.; Korrovits, P.; Metspalu, A.; Krjutškov, K.; Nõlvak, H.; Preem, J.-K.; et al. Complementary Seminovaginal Microbiome in Couples. Res. Microbiol. 2015, 166, 440-447. [CrossRef]

32. Barbonetti, A.; Cinque, B.; Vassallo, M.R.C.; Mineo, S.; Francavilla, S.; Cifone, M.G.; Francavilla, F. Effect of Vaginal Probiotic Lactobacilli on in Vitro-Induced Sperm Lipid Peroxidation and Its Impact on Sperm Motility and Viability. Fertil. Steril. 2011, 95, 2485-2488. [CrossRef]

33. Kiessling, A.A.; Desmarais, B.M.; Yin, H.-Z.; Loverde, J.; Eyre, R.C. Detection and Identification of Bacterial DNA in Semen. Fertil. Steril. 2008, 90, 1744-1756. [CrossRef] [PubMed]

34. Liu, C.M.; Osborne, B.J.W.; Hungate, B.A.; Shahabi, K.; Huibner, S.; Lester, R.; Dwan, M.G.; Kovacs, C.; Contente-Cuomo, T.L.; Benko, E.; et al. The Semen Microbiome and Its Relationship with Local Immunology and Viral Load in HIV Infection. PLoS Pathog 2014, 10, e1004262. [CrossRef] [PubMed]

35. Sanocka-Maciejewska, D.; Ciupińska, M.; Kurpisz, M. Bacterial Infection and Semen Quality. J. Reprod. Immunol. 2005, 67, 51-56. [CrossRef] [PubMed]

36. Farahani, L.; Tharakan, T.; Yap, T.; Ramsay, J.W.; Jayasena, C.N.; Minhas, S. The Semen Microbiome and Its Impact on Sperm Function and Male Fertility: A Systematic Review and Meta-Analysis. Andrology 2021, 9, 115-144. [CrossRef]

37. Althouse, C.; Skaife, J.; Loomis, P. Prevalence and Types of Contaminant Bacteria in Extended, Chilled Equine Semen. Anim. Reprod. Sci. 2010, 121, 224-225. [CrossRef]

38. Madsen, M.; Christensen, P. Bacterial Flora of Semen Collected from Danish Warmblood Stallions by Artificial Vagina. Acta Vet. Scand. 1995, 36, 1-7.

39. Pickett, B.W.; Voss, J.L.; Jones, R.L. Control of Bacteria in Stallions and Their Semen. J. Equine Vet. Sci. 1999, 19, 424-469. [CrossRef]

40. Varner, D.D.; Scanlan, C.M.; Thompson, J.A.; Brumbaugh, G.W.; Blanchard, T.L.; Carlton, C.M.; Johnson, L. Bacteriology of Preserved Stallion Semen and Antibiotics in Semen Extenders. Theriogenology 1998, 50, 559-573. [CrossRef] 
41. Mändar, R. Microbiota of Male Genital Tract: Impact on the Health of Man and His Partner. Pharmacol. Res. 2013, 69, 32-41. [CrossRef]

42. Asadi, A.; Ghahremani, R.; Abdolmaleki, A.; Rajaei, F. Role of Sperm Apoptosis and Oxidative Stress in Male Infertility: A Narrative Review. Int. J. Reprod. Biomed. 2021, 19, 493-504. [CrossRef]

43. Hannachi, H.; Elloumi, H.; Hamdoun, M.; Kacem, K.; Zhioua, A.; Bahri, O. Bacteriospermia: Effects on semen parameters. Gynecol. Obstet. Fertil. Senol. 2018, 46, 518-523. [CrossRef] [PubMed]

44. Weidner, W.; Anderson, R.U. Evaluation of Acute and Chronic Bacterial Prostatitis and Diagnostic Management of Chronic Prostatitis/Chronic Pelvic Pain Syndrome with Special Reference to Infection/Inflammation. Int. J. Antimicrob. Agents 2008, 31 (Suppl. S1), S91-S95. [CrossRef] [PubMed]

45. Schulze, M.; Dathe, M.; Waberski, D.; Müller, K. Liquid Storage of Boar Semen: Current and Future Perspectives on the Use of Cationic Antimicrobial Peptides to Replace Antibiotics in Semen Extenders. Theriogenology 2016, 85, 39-46. [CrossRef] [PubMed]

46. Corona, A.; Cossu, I.; Bertulu, A.; Cherchi, R. Characterisation of Bacteria in Fresh Semen of Stallions during the Breeding Season. Anim. Reprod. Sci. 2006, 94, 85-88. [CrossRef]

47. Lundy, S.D.; Sangwan, N.; Parekh, N.V.; Selvam, M.K.P.; Gupta, S.; McCaffrey, P.; Bessoff, K.; Vala, A.; Agarwal, A.; Sabanegh, E.S.; et al. Functional and Taxonomic Dysbiosis of the Gut, Urine, and Semen Microbiomes in Male Infertility. Eur. Urol. 2021, 79, 826-836. [CrossRef]

48. Pasing, S.S.; Aurich, C.; von Lewinski, M.; Wulf, M.; Krüger, M.; Aurich, J.E. Development of the Genital Microflora in Stallions Used for Artificial Insemination throughout the Breeding Season. Anim. Reprod. Sci. 2013, 139, 53-61. [CrossRef]

49. Namdari, S.; Nicholson, T.; Abboud, J.; Lazarus, M.; Ramsey, M.L.; Williams, G.; Parvizi, J. Comparative Study of Cultures and Next-Generation Sequencing in the Diagnosis of Shoulder Prosthetic Joint Infections. J. Shoulder Elbow Surg. 2019, $28,1-8$. [CrossRef]

50. Mändar, R.; Punab, M.; Korrovits, P.; Türk, S.; Ausmees, K.; Lapp, E.; Preem, J.-K.; Oopkaup, K.; Salumets, A.; Truu, J. Seminal Microbiome in Men with and without Prostatitis. Int. J. Urol. 2017, 24, 211-216. [CrossRef] 